\title{
ANNA LISA SCHINO, Batailles libertines. La vie et l'œuvre de Gabriel Naudé
}

\section{Laura Rescia}

\section{OpenEdition}

\section{Journals}

\section{Edizione digitale}

URL: https://journals.openedition.org/studifrancesi/43808

DOI: 10.4000/studifrancesi.43808

ISSN: 2427-5856

\section{Editore}

Rosenberg \& Sellier

\section{Edizione cartacea}

Data di pubblicazione: 1 juin 2021

Paginazione: 211

ISSN: 0039-2944

\section{Notizia bibliografica digitale}

Laura Rescia, "Anna LISA Schino, Batailles libertines. La vie et l'œuvre de Gabriel Naudé», Studi Francesi [Online], 193 (LXV | I) | 2021, online dal 01 juillet 2021, consultato il 15 octobre 2022. URL: http:// journals.openedition.org/studifrancesi/43808; DOI: https://doi.org/10.4000/studifrancesi.43808

Questo documento è stato generato automaticamente il 15 octobre 2022.

\section{@(@) $\Theta \Theta$}

Creative Commons - Attribuzione - Non commerciale - Non opere derivate 4.0 Internazionale - CC BY NC-ND 4.0

https://creativecommons.org/licenses/by-nc-nd/4.0/ 


\title{
ANNA LISA SCHINO, Batailles libertines. La vie et l'œuvre de Gabriel Naudé
}

\author{
Laura Rescia
}

\section{NOTIZIA}

ANNA LISA SCHINO, Batailles libertines. La vie et l'œuvre de Gabriel Naudé, Paris, Honoré Champion, 2020, «Libre pensée et littérature clandestine» 76, 340 pp.

1 Pubblicato in lingua italiana nel 2014, nei "Quaderni del Giornale Critico della Filosofia Italiana", questo saggio viene oggi tradotto in francese a cura di S. Vermot-PetitOuthenin per la collana di Garnier diretta da A. Mc Kenna. Viene presentata la figura di Gabriel Naudé, che fu come noto bibliotecario, medico, appartenente al novero dei libertini eruditi, la cui formazione padovana - fu allievo di Cremonini - si tradusse in una prospettiva naturalistica e materialistica. Feroce oppositore del sovrannaturale, adottò una prospettiva storico-critica, a cui guardò con attenzione Pierre Bayle, e una scrittura interamente orientata alla dissimulazione, grazie alla quale espresse la sua convinta libertà intellettuale, ostile al fanatismo teologico e alla superstizione popolare. Il saggio ne ripercorre l'opera e il pensiero, utilizzando anche lo spoglio sistematico della sua corrispondenza. Il volume di Garnier offre una traduzione accurata e puntuale del testo dell'A., le cui citazioni latine vengono tradotte in questa versione francese, che offre altresì una bibliografia delle fonti e critica assente dal volume italiano. 